\title{
Evaluation of Selected Site Location for Subsurface Dam Construction within Isayi Watershed Using GIS and RS Garmiyan Area, Kurdistan Region
}

\author{
Salahaldin S. Ali', Foad A. Al-Umary², Sarkawt G. Salar ${ }^{3}$, Nadhir Al-Ansari4 ${ }^{*}$, Sven Knutsson ${ }^{4}$ \\ ${ }^{1}$ Department of Geology, School of Science, Faculty of Science and Science Education, University of \\ Sulaimaniyah, Iraqi Kurdistan Region, Iraq \\ ${ }^{2}$ Department of Geography, College of Education, University of Tikrit, Tikrit, Iraq \\ ${ }^{3}$ Department of Geography, Faculty of Education, University of Garmian, Iraqi Kurdistan Region, Iraq \\ ${ }^{4}$ Department of Civil, Environmental and Natural Resources Engineering, Lulea University of Technology, \\ Lulea, Sweden \\ Email: salahsulus@yahoo.com, abidnaif@yahoo.com, sarkawtgeo@yahoo.com, \\ sven.Knutsson@ltu.se
}

Received 28 June 2014; revised 22 July 2014; accepted 7 August 2014

Copyright (C) 2014 by authors and Scientific Research Publishing Inc.

This work is licensed under the Creative Commons Attribution International License (CC BY).

http://creativecommons.org/licenses/by/4.0/

c. (i)

\begin{abstract}
Garmiyan area suffers from many water problems such as poor rainfall rate, water shortage, aridity and absence of groundwater in many places. Hence the subsurface dam is the best solution due to many advantages such as low cost of construction, least maintenance, low evaporation, no contamination, utilization of the land over the dam and better storage. The objective of this study is to evaluate the suitability of the selected site location for subsurface dam construction, to serve as strategic water supply storage, to solute the aridity and water shortage in this area of arid to semi arid climate in Isayi watershed within the stream deposits. Geographic information systems (GIS) and remote sensing through satellite images and Digital Elevation Model (DEM) interpretation and analysis have facilitated the investigation with more accuracy. ArcGIS helped in construction of thematic maps of the studied area. The geologic, structural, geomorphologic, hydrologic and hydrogeologic characteristics with GPR survey show the suitability of the selected site location for construction of subsurface dam. According to the standard water quality for domestic, irrigation and livestock the water quality of all water samples are within the recommended range and the best time to be chosen, for construction of the subsurface dam, is during the autumn season from September to November.
\end{abstract}

\footnotetext{
${ }^{*}$ Corresponding author.
}

How to cite this paper: Ali, S.S., Al-Umary, F.A., Salar, S.G., Al-Ansari, N. and Knutsson, S. (2014) Evaluation of Selected Site Location for Subsurface Dam Construction within Isayi Watershed Using GIS and RS Garmiyan Area, Kurdistan Region. Journal of Water Resource and Protection, 6, 972-987. http://dx.doi.org/10.4236/jwarp.2014.611092 


\section{Keywords}

\section{Subsurface Dam, GIS, Water Harvest, Hydrogeology, Geomorphology}

\section{Introduction}

One of the best solutions to overcome the aridity and drought problems in arid and semi-arid areas is building under-ground storage dams (sub-surface dams). According to Ishida et al. [1], Borst and de Haas [2], Hoogmoed [3], Şen [4] and Khairy et al. [5], such technique has many advantages like decrease of evaporation, decrease of contamination, no problem of land submergence, no silting, no danger of breaching and low construction cost. The studied area is located about $42 \mathrm{~km}$ south of Darbandikhan district and $123 \mathrm{~km}$ east of Kirkuk city with 19

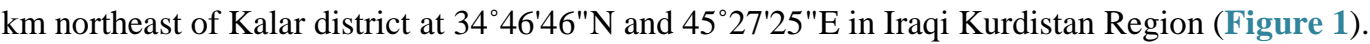

The aim of the present study is to construct an aquifer (subsurface dam) with high productivity, to serve different human activities and combat aridity and drought that dominates the area.

\section{Methodology}

The methodology used, to identify appropriate sites for the proposed subsurface dams at the outlet of Isayi watershed within the stream deposits, consists of following steps using ArcGIS 9.3 and Global Mapper 11:

- Visual interpretations of satellite imagery to delineate the geology and geomorphologic units.

- Field verification of interpreted units.

Ground Penetration Radar (GPR) survey had been used to display clear information about the presence of subsurface structure by drawing two profiles; the first profile runs across the ephemeral stream and trending NW-SE, with a length equal to $288 \mathrm{~m}$; and the second profile runs parallel to the first profile and trending NW-SE with a length equal to $340 \mathrm{~m}$.

- Drawing geologic cross section using Adobe Illustrator.

- Temperature and rainfall data for the period (1995-2009) were used in the interpretation.

- Stream discharge was measured using staff gauge method.

- Slope map and profile were prepared using Digital Elevation Model (DEM).

- Groundwater level fluctuations were monitored within the stream deposit for the entire year.

- Hydrogeological and hydrochemical characteristics of the stream deposits were evaluated using pumping and packer tests.

\section{Geologic Setting}

The present area tectonically lies within the low folded zone. It is part of southwestern limb of Chamchamal south anticline. The pre-Quaternary basement of the site location consists of the Mukdadiya Formation, which is of Upper Miocene to Pliocene Age (Figure 2) [6].

The area is composed of alternation beds of claystone, siltstone and sandstone, crossed by Isayi main stream valley that is filled with alluvial deposits. The alluvial deposits are composed of mixture of clay, sand, pebbles and cobbles. The grains size of this mixture is increasing downstream due to washing and removing of the fine grain sediments by the continuous flow of subsurface water as interflow. According to Şen [4], the coarse structure of alluvial deposits minimizes capillary effects and losses by evaporation. Both sides of the selected site are composed of claystone overlaid by thick, hard, jointed and course grained pebbly sandstone.

These sedimentary rocks can be grouped into permeable and impermeable layers. The permeable layer represented by the stream deposits, with width of $340 \mathrm{~m}$ and thickness ranging between 3 to $7 \mathrm{~m}$ reaching its maximum at the southern part of the section (Figure 3). It will form the reservoir upstream of the project's body. The impermeable layer consists of $52 \mathrm{~m}$ of claystone under the first layer of alluvial bed.

\section{Geologic Structure}

The rock strata, at the selected site location for the subsurface dam is part of the southwestern limb of Chamchamal south anticline. These rocks are dipping $30^{\circ}$ with dip direction of $\mathrm{S} 70^{\circ} \mathrm{E}$. The thickness of claystone and 




Figure 1. Location of the proposed subsurface dam within Isayi watershed.

sandstone are 52 and $5 \mathrm{~m}$ respectively, while the thickness of alluvial beds is ranging from 3 to $7 \mathrm{~m}$. Generally, the stream direction is parallel to the strike. Whereas, the stream at the selected site location crosses and cuts the bed rocks with $80^{\circ}$ angle from northwest to southeast. The geological and structural situations provide suitable conditions for the proposed subsurface dam construction, which will act as natural barrier and both flanks of the subsurface dam can be supported on them. The GPR survey results of the valley floor over the alluvial deposits revealed that the selected site location is very well for the construction of a subsurface dam across the valley (Figure 4 and Figure 5), because no evidence of faults and cavities were recorded beneath the whole area under consideration.

\section{Climate}

Rainfall is the basic and direct source of recharge for all kinds of water resources within Isayi watershed (Figure 6). Its contribution to groundwater recharge is not regular and uniform throughout the year in all parts of the watershed. Its variation in time and space directly influence the formation and distribution of surface and subsurface water. The upper reach of the watershed receives more rainfall than the lower reach due to the relatively high elevation that exceeds $1000 \mathrm{~m}$. This is evidenced by the flash floods that were recorded the outlet in the absence of rainfall.

\section{Structure Runoff}

The hydrologic behavior of the stream flow is affected by the watershed characteristic. Water flows in Isayi stream from autumn to the end of spring (Figure 7) and it is obvious that the stream is directly recharged by rainfall. The average daily flow reaches $22,107 \mathrm{~m}^{3} /$ day. Most of the watershed is covered by fine grain sedimentary rocks of low permeability and infiltration rate. The area of Isayi watershed, till the location of the proposed first subsurface dam is $145 \mathrm{~km}^{2}$ that has been classified as large watershed on the basis of Şen [4]. 


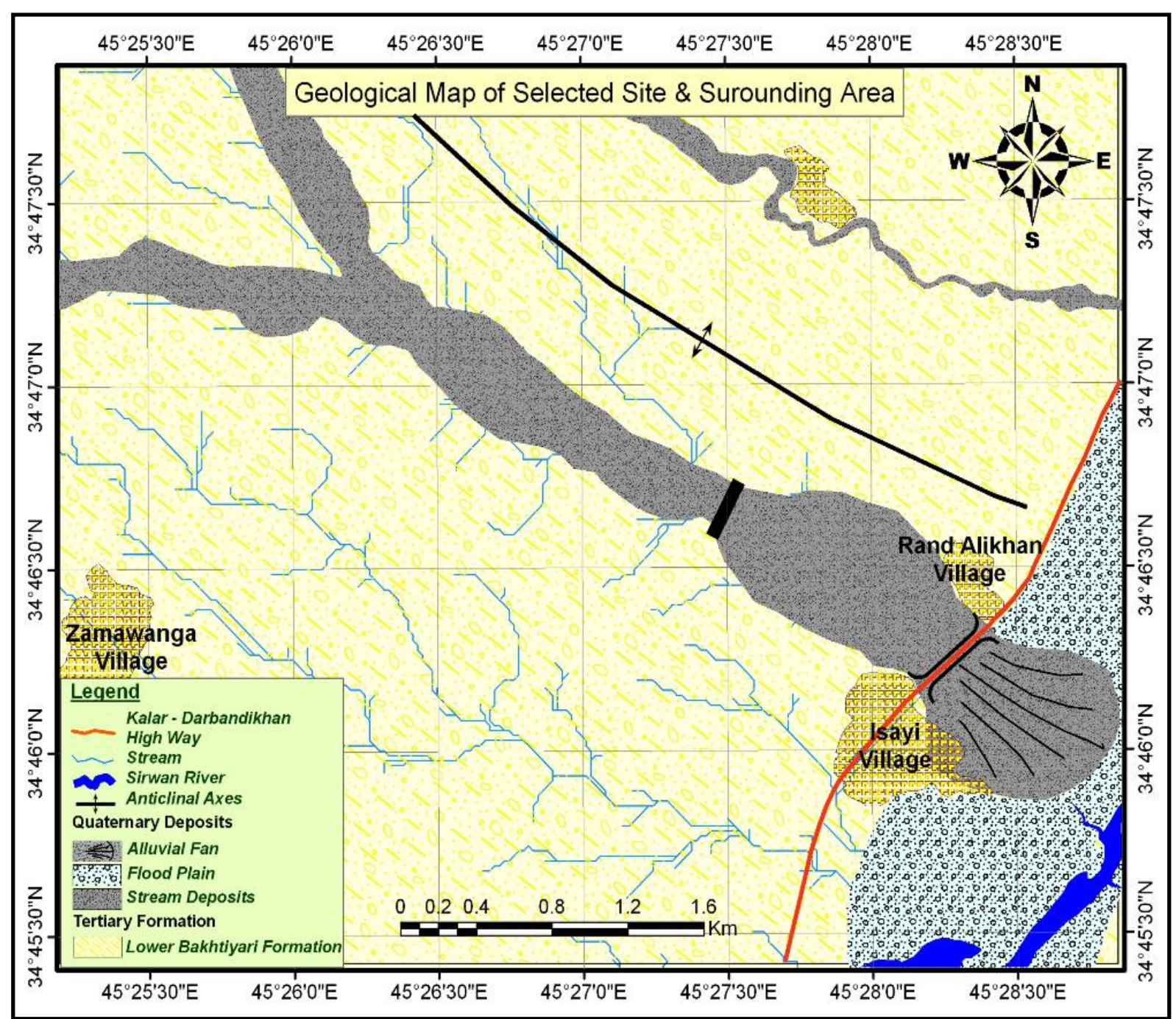

Figure 2. Geological map of the selected site location for construction of subsurface dam.



Figure 3. Geologic cross section for the proposed subsurface dam's selected site location. 


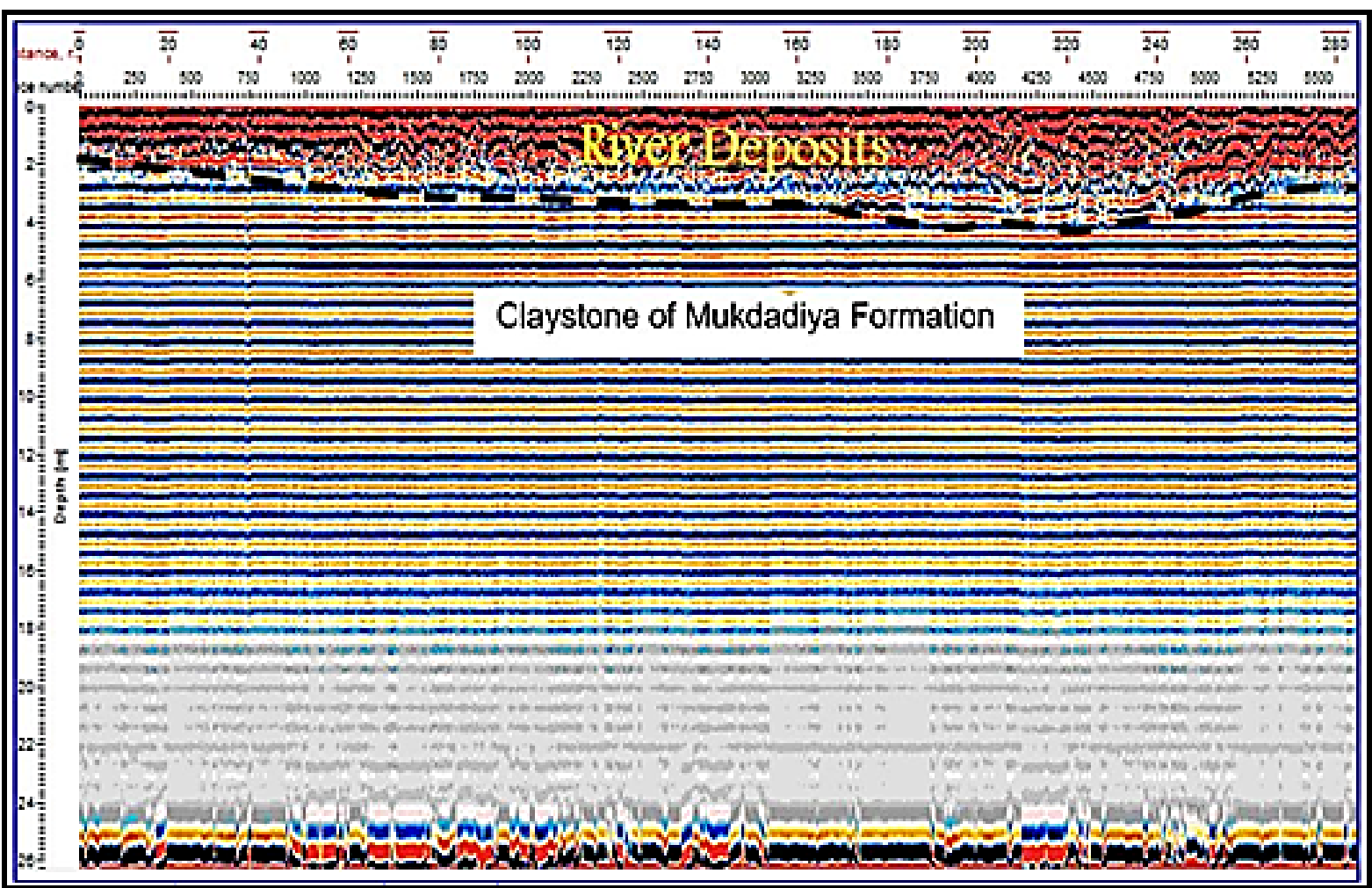

Figure 4. Radar section of the profile NO.1.



Figure 5. Radar section of the profile NO.2. 


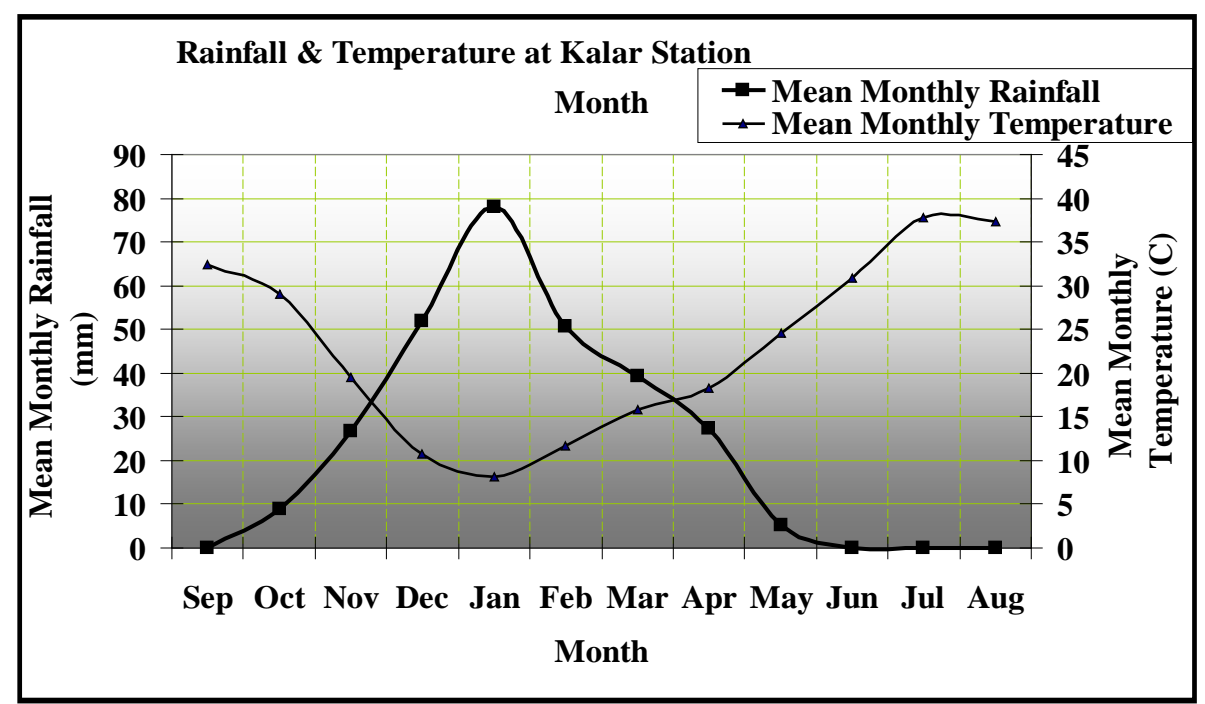

Figure 6. Annual variation of rainfall and temperature according to humid and arid month's distribution.

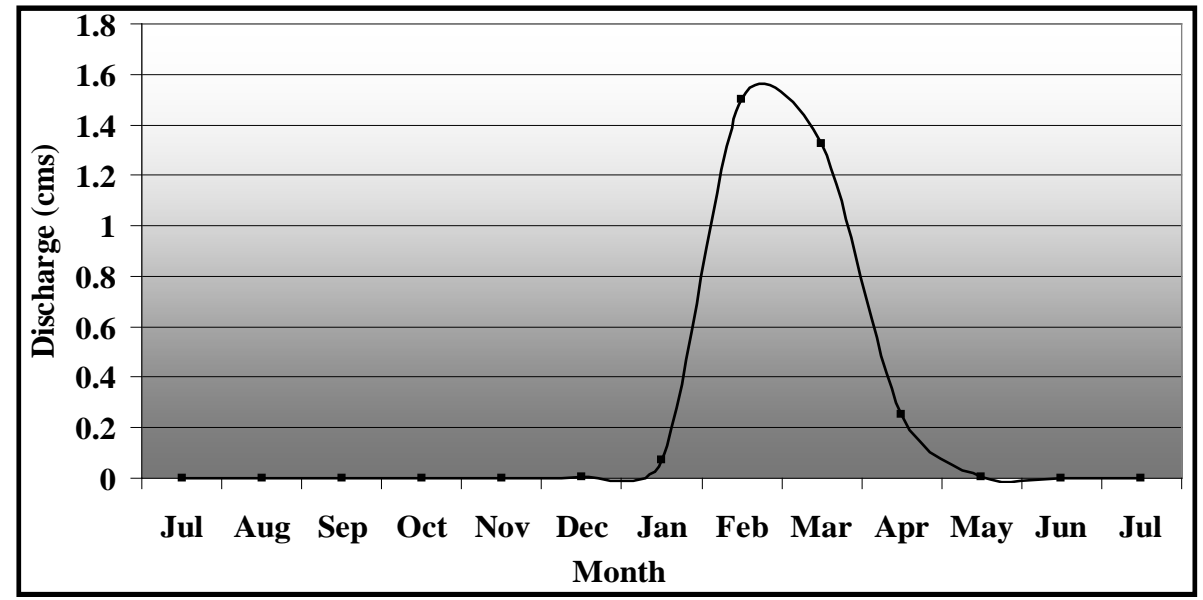

Figure 7. Stream hydrograph in the studied area.

\section{Geomorphology}

Geological features in terms of rock outcrops and geomorphologic characteristics are important for water resources occurrence, distribution, and movement in any wadi (valley) system [4]. Geomorphologic features or landforms have a great effect on the types of the projects to be implemented. As it is recommended by Nilsson [7], Danida [8] and Ali [9], that suitable geomorphic landforms for the construction of subsurface dam at the site location is alluvial deposits valley with low gradient at the outlet of the watershed. The characteristics of the suggested site are as follow (Figure 8):

- Watershed Outlet

The selected site for the subsurface dam is located at the outlet (mouth) of shallow and elongated valley, nearly $2.2 \mathrm{~km}$ southeast the confluence of the two main branches of the watershed, which are supplying water to this main valley. This site location lays $1.5 \mathrm{~km}$ west of Kalar and Darbandikhan road at Isayi and Randalikhan villages (Figure 8).

The main stream is constant and straight with very gentle slope which removes the risks of bypass. The surface and subsurface water flow down and pass the watershed's outlet with adequate discharge in other word good quantity of water.

- Alluvial Deposits Valley 


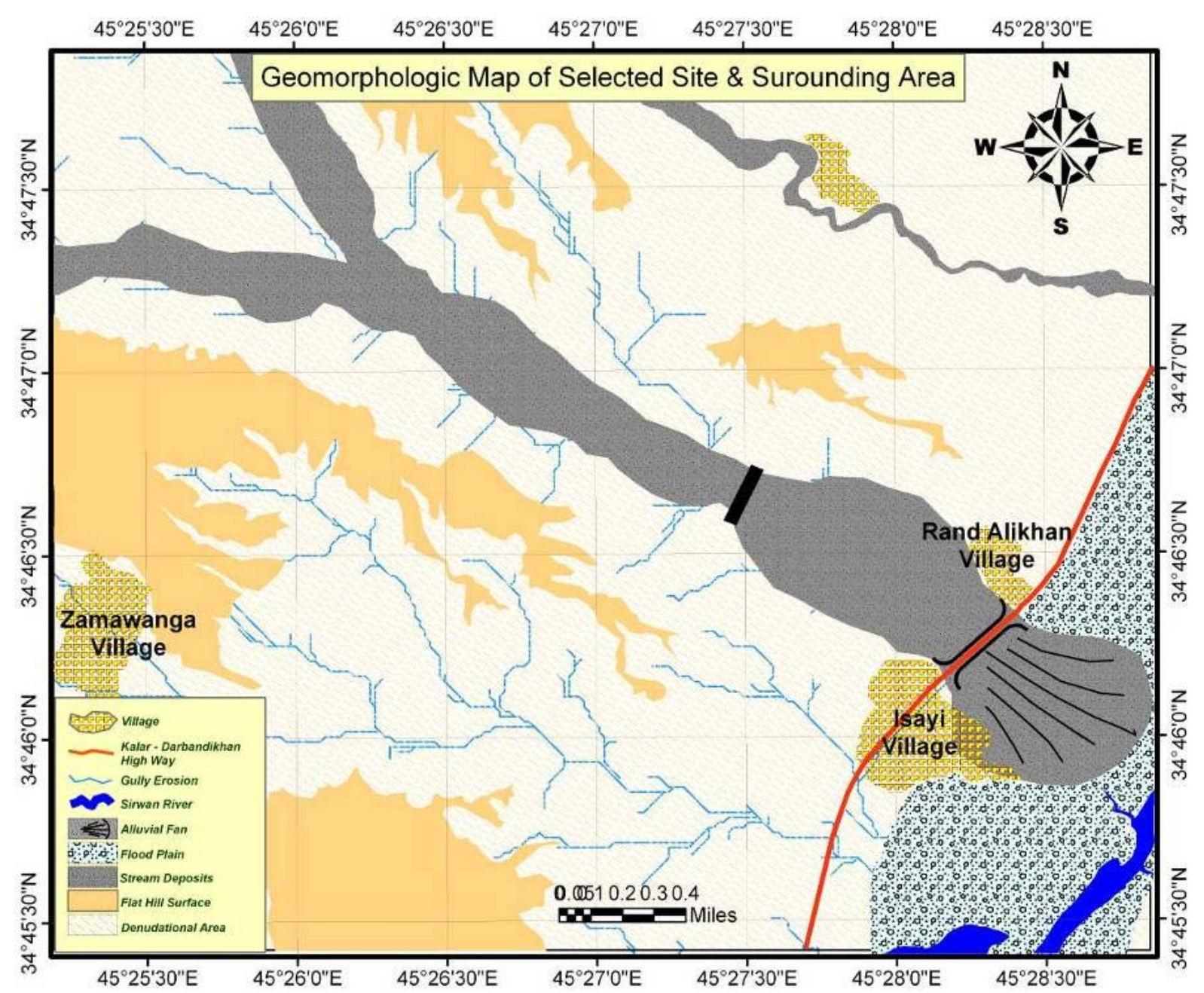

Figure 8. Geomorphological map of the selected site location of the proposed subsurface dam.

The valley chosen is an alluvial deposits valley. From geomorphic and geological structure perspective it meets the requirements for building subsurface dam. Its lithology enables percolation and infiltration of water into the porous and unconsolidated sediment. It preserves the water of the stream as subsurface water interflow. In addition, it does not have irregular water bypaths and this means less risk of water leakage. This is due to the fact that the valley's sides are of impermeable bed rocks represented byclaystone.

- Gradient or Slope

Sites with minimum topographical gradient will render best services for building the subsurface dam [7]-[9]. The slope of the alluvial deposits is level to very gentle $\left(0^{\circ}-2^{\circ}\right.$ degrees with an average value of $\left.1.7^{\circ}\right)$ which is within the recommended limits (Figure 9). This level or very gentle slope will allow more and enough time for water infiltration into alluvial deposits, which will be beneficial for rapid storage, and increase of subsurface dam capacity due to the increase of sedimentation upstream of subsurface dam body.

\section{Hydrology}

In order to identify hydrogeological characteristics of the alluvial deposits the following detailed field surveys were carried out at the selected site location:

\subsection{Subsurface Water Level Observations}

The groundwater level depends on the annual and seasonal recharge of the alluvial deposits by rainfall. The 


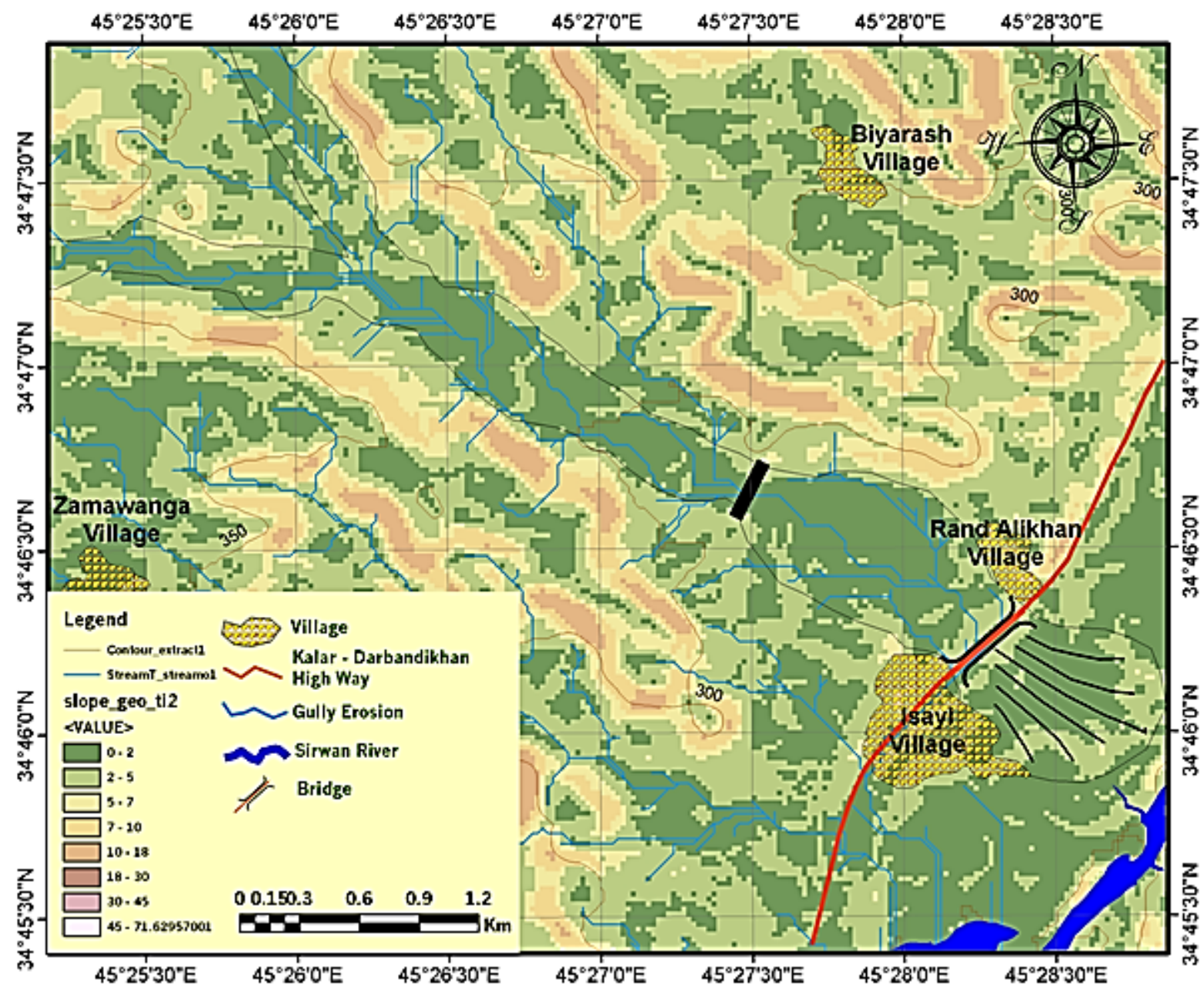

Figure 9. Topographic and slope maps of selected site location for subsurface dam project.

groundwater level is rising and dropping concordant with wet and dry seasons respectively (Figure 10). The maximum drop of groundwater level was at autumn season (2011), while the minimum drop was during the spring season (2012). The reason behind the maximum drop of groundwater level, within the stream deposits at autumn, is the ceasing of groundwater recharge by rainfall.

Although the groundwater level is dropping during dry period within the stream deposits, but it is flowing continuously through the whole year as interflow toward Sirwan River. This is the most important characteristic of the study area, because the upstream parts of the drainage basin receives more water as orographic rainfall feeding the main channel due to high elevations.

\subsection{Hydraulic Characteristic of Open Well}

A dug well situated on the stream deposit of Isayi watershed at an elevation of $390 \mathrm{~m}$ above sea level was tested. The aquifer layer of the well is a mixture clay, sand and gravel, which is completely penetrated by the dug well and unconfined in type. The nature of the aquifer is characterized mainly by inter granular mixture of sands and gravels.

If the water is pumped in alluvial deposits at a high rate the depression head will increase, which may cause excess gradients Raghunath (2006). Then these data will substitute into appropriate well-flow equation and the hydraulic characteristics of the aquifer can be calculated. According to Raghunath [10] proper analyses of these data lead to the determination of hydraulic characteristics such as specific yield (Sy), specific capacity (Sc), safe yield (Qy), transmissibility (T) or hydraulic and conductivity (permeability) (Kf). 


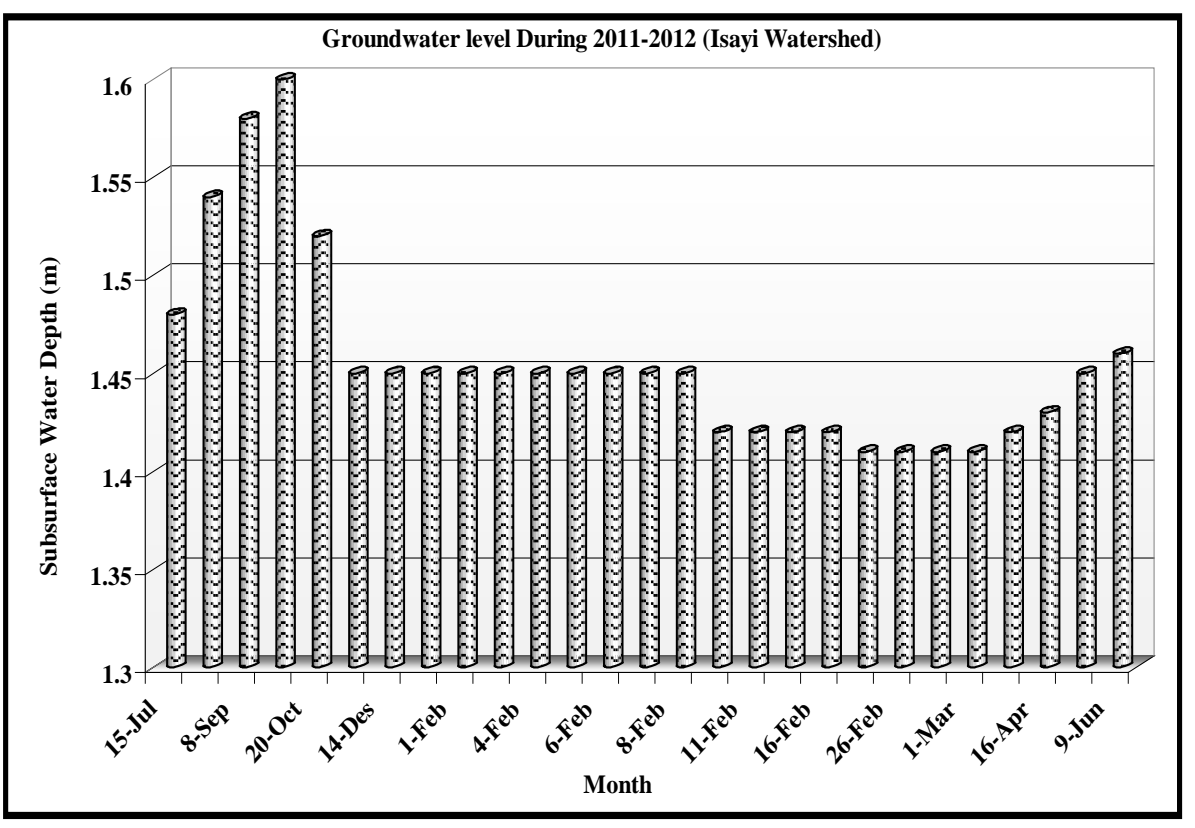

Figure 10. Observed groundwater level fluctuation within the stream deposits.

Among the 8 productive hand dug wells, within the stream deposits upstream Randalikhan village in Isayi watershed, pumping test was conducted at one dug well in which the pumping operation took 31 minutes. The recovery duration time was 21 minutes. The dimension of the dug well was $3.60 \mathrm{~m}$ deep and with $0.75 \mathrm{~m}$ in diameter. The delivery rate of the pump for the well was constant at a rate of $28.811 \mathrm{~m}^{3} /$ hour. Accordingly, the pumping test duration is relatively slower than the recovery rate.

In the pumping test, the water level in the well was depressed to an amount equal to the safe working head for the sub-soil. Then the water level was kept constant by making the pumping rate equal to the percolation of water into the well [10]. The quantity of water pumped in a known time gives an idea of the probable yield of the well of the given diameter. The test had been carried out in an existing open well within the stream deposits in Isayi watershed.

Let the water level inside the well rise from s1 to s2 which is measured below static water level (swl) in time (T). If (s) is the head at any time (t), from Darcy's law then:

$$
\mathrm{Q}=\mathrm{K} \text { A I }
$$

where:

$$
\begin{aligned}
& \mathrm{I}=\text { Hydraulic head } \\
& \mathrm{A}=\text { cross sectional area } \\
& \mathrm{K}=\text { Hydraulic conductivity } \\
& \mathrm{Q}=\text { Discharge }
\end{aligned}
$$

According to Raghunath [10], the value of Sy is usually determined from a recuperation test and $(\mathrm{Q}=\mathrm{Sy})$ when $(A=1, H=1)$, i.e., the specific yield of the soil is the discharge per unit area under a unit depression head and has dimension of $\mathrm{T}-1$ (l/time) and the usual values are:

Sy $=0.25 \mathrm{hr}-1$ for clayey soil

Sy $=0.50 \mathrm{hr}-1$ for fine sand

Sy $=1.00 \mathrm{hr}-1$ for coarse sand

The recovery test has been done during 22 minutes after the pumping stopped as illustrated in Table 1 . The total volume of water pumped during 31 minutes of pumping was $14.89 \mathrm{~m}^{3}$.

\subsection{Packer Test}

According to Fetter and Brassington [11] [12], packer test is an aquifer test performed in an open borehole and the segment of the aquifer to be tested, it should be sealed off by inflating seals in the borehole, called packer, 
Table 1. Hydraulic characteristics of open well within the stream deposits.

\begin{tabular}{cccc}
\hline Time Since Pumping Stopped (min) & $\begin{array}{c}\text { Water Level Depth } \\
(\mathrm{m})\end{array}$ & $\begin{array}{c}\text { Residual Drawdown } \\
\text { S2 }=\text { WL }- \text { SWL }(\mathrm{m})\end{array}$ & Ratio (s1/s2) \\
\hline 0.000 & 3.45 & 1.95 & 1.000 \\
1.000 & 2.9 & 1.4 & 1.393 \\
2.000 & 2.69 & 1.19 & 1.639 \\
3.000 & 2.48 & 0.98 & 1.990 \\
4.000 & 2.29 & 0.79 & 2.468 \\
5.000 & 2.14 & 0.64 & 3.047 \\
6.000 & 2.01 & 0.51 & 3.824 \\
7.000 & 1.89 & 0.39 & 5.000 \\
8.000 & 1.8 & 0.3 & 6.500 \\
9.000 & 1.75 & 0.25 & 7.800 \\
10.000 & 1.7 & 0.2 & 9.750 \\
11.000 & 1.68 & 0.18 & 10.833 \\
12.000 & 1.66 & 0.16 & 12.188 \\
13.000 & 1.645 & 0.145 & 13.448 \\
14.000 & 1.63 & 0.13 & 15.000 \\
15.000 & 1.625 & 0.125 & 15.600 \\
16.000 & 1.62 & 0.12 & 16.250 \\
17.000 & 1.61 & 0.11 & 17.727 \\
18.000 & 1.605 & 0.105 & 18.571 \\
19.000 & 1.6 & 0.1 & 19.500 \\
20.000 & 1.595 & 0.095 & 20.526 \\
21.000 & 1.59 & 0.09 & 21.667 \\
& 1.585 & 0.085 & 22.941 \\
\hline
\end{tabular}

both above and below the segment. It is used to determine the permeability of the rock strata, in the boreholes.

In this project, four boreholes were drilled using drilling machine for shallow wells. Core samples have been taken during drilling. They were used to estimate the lithology and geological structure (Table 2). Packer test was carried out to assess claystone bed rock that underlies the alluvial deposits in the studied area by calculating the transmissivity and permeability to ensure that the aquifer for the dam should be underlain with bedrock having low permeability to retain water for collection and to prevent seepage. Injection test has been used for $3 \mathrm{~m}$ of claystone of the borehole and injecting water under pressure into the rock to determine the effective transmissivity $(\mathrm{T})$ of the zone. However, it was particularly easy to distinguish the unconsolidated permeable stream deposits layer from the impermeable basement rock that is represented by claystone. These boreholes have been used for packer test process to assess the hydraulic conductivity or permeability of the claystone that underlies the stream deposits.

\subsection{Result}

The continuous groundwater flow, within the stream deposits, was continuously supplying water for different purposes through the whole year even during the dry season. According to the results of the pumping test (Table 3), the stream deposits can be classified as moderate according to Şen [13] as illustrated in Table 4. The stream deposits at the selected site location for the subsurface dam can be considered as unconfined aquifer because there is no impermeable rock stratum ceasing its upper part. The results of the groundwater discharge revealed that the discharge depends on the seasonal groundwater level fluctuations through whole year. This is due to the fact that it is recharged by rainfall and it flows continuously within the stream deposits to discharge Sirwan River through the whole year. During the wet season the groundwater discharge shows high value whereas during the dry season the groundwater discharge is decreasing.

During the packer test, the flow rate did not change with increasing the exerted pressure and remains the 
Table 2. Characteristics of the drilled boreholes at the site location for subsurface dam construction.

\begin{tabular}{|c|c|c|c|c|}
\hline $\begin{array}{l}\text { Well } \\
\text { NO. }\end{array}$ & $\begin{array}{l}\text { Depth of } \\
\text { Well (m) }\end{array}$ & Lithology & $\begin{array}{l}\text { Depth of Water } \\
\text { Table }(\mathrm{m})\end{array}$ & Remarks \\
\hline 1 & 4 & $\begin{array}{c}\text { First } 2 \mathrm{~m} \text { layer is unconsolidated stream } \\
\text { deposits and the rest is claystone }\end{array}$ & 1.5 & \\
\hline 2 & 7.5 & $\begin{array}{c}\text { First } 6.73 \text { m layer is unconsolidated stream } \\
\text { deposits and the rest is claystone }\end{array}$ & 1.5 & $\begin{array}{l}\text { The thickness of the unconsolidated } \\
\text { materials reaches its maximum at } \\
\text { well NO.2 at southern part of the } \\
\text { section. The clay content within the }\end{array}$ \\
\hline 3 & 7 & $\begin{array}{c}\text { First } 4 \mathrm{~m} \text { layer is unconsolidated stream } \\
\text { deposits and the rest is claystone }\end{array}$ & 1.5 & $\begin{array}{l}\text { unconsolidated materials decrease down } \\
\text { ward due to washing by flowing } \\
\text { interflow within the stream deposits }\end{array}$ \\
\hline 4 & 3.20 & $\begin{array}{l}\text { First } 3.5 \mathrm{~m} \text { layer is unconsolidated stream } \\
\text { deposits and the rest is sandstone }\end{array}$ & 1.5 & \\
\hline
\end{tabular}

\section{Table 3. Hydrogeologic characteristics of the stream deposits at the study area.}

\begin{tabular}{|c|c|c|c|c|}
\hline $\begin{array}{l}\text { Hydrogeological } \\
\text { Parameters }\end{array}$ & & Equation & Author & Values \\
\hline Rate of Delivery & l & 1 & $\begin{array}{l}\text { Raghunath } \\
\text { (2006) }\end{array}$ & \\
\hline $\begin{array}{l}\text { Rate of Seepage } \\
\left(Q_{\text {seepage }}\right)\end{array}$ & $\begin{array}{c}Q_{\text {seepage }}=\left(Q t-\left(\left(\pi D^{2} / 4\right) \times\right.\right. \\
d)) / t\end{array}$ & $\begin{array}{c}D=\text { diameter of the well (m). } \\
d=\text { depth of water column (m). } \\
Q=\text { pumping rate }\left(\mathrm{m}^{3} / \text { hour }\right) \text {. } \\
t=\text { time required for emptying the well (hour). }\end{array}$ & $\begin{array}{l}\text { Raghunath } \\
\text { (2006) }\end{array}$ & $\begin{array}{c}10.95 \\
\mathrm{~m}^{3} / \text { hour }\end{array}$ \\
\hline Specific Yield $\left(S_{y}\right)$ & $S_{y}=(2.303 / \mathrm{T}) \log _{10} \mathrm{~s} 1 / \mathrm{s} 2$ & $\begin{array}{c}\mathrm{s} 1 / \mathrm{s} 2=\text { desidual drawdown ratio } \\
T=\text { Time required for water level rising (hour). }\end{array}$ & $\begin{array}{l}\text { Raghunath } \\
\text { (2006) }\end{array}$ & $\begin{array}{c}8.546 \\
\mathrm{hr}^{-1}\end{array}$ \\
\hline Specific Capacity $\left(S_{c}\right)$ & $S c=S_{y} \times A$ & $\begin{array}{c}S_{y}=\text { Specific yield of the stream deposits. } \\
\qquad A=\text { Area of the dug well section }\end{array}$ & $\begin{array}{l}\text { Raghunath } \\
\text { (2006) }\end{array}$ & $\begin{array}{l}90.624 \\
\mathrm{~m}^{2} \text { day }^{-1}\end{array}$ \\
\hline $\begin{array}{l}\text { Safe Yield } \\
\quad(Q y)\end{array}$ & $Q_{y}=S_{y} A H$ & $\begin{array}{c}Q_{y}=\text { safe yield of the well }\left(\mathrm{m}^{3} / \mathrm{s}\right) . \\
A=\text { area of cross section of the well }\left(\mathrm{m}^{2}\right) . \\
H=\text { Safe working depression head }(\mathrm{m}) . \\
S_{y}=\text { Specific yield of the soil. }\end{array}$ & $\begin{array}{l}\text { Raghunath } \\
\text { (2006) }\end{array}$ & $\begin{array}{c}176.694 \\
\mathrm{~m}^{3} / \text { day }\end{array}$ \\
\hline Transmissibility ( $T$ ) & $T=S_{c} \times 1.2$ & $\begin{array}{c}T=\text { Transmissibility }\left(\mathrm{m}^{2} / \mathrm{d}\right) \\
S_{c}=\text { Specific Capacity }\end{array}$ & $\begin{array}{l}\text { Raghunath } \\
\text { (2006) }\end{array}$ & $\begin{array}{c}108.749 \\
\mathrm{~m}^{2} / \text { day }\end{array}$ \\
\hline $\begin{array}{c}\text { Hydraulic } \\
\text { Conductivity }(K)\end{array}$ & $K=T / H$ & $\begin{array}{l}T=\text { Transmissibility }\left(\mathrm{m}^{2} / \mathrm{d}\right) . \\
H=\text { Saturated thickness }(\mathrm{m})\end{array}$ & $\begin{array}{l}\text { Raghunath } \\
\text { (2006) }\end{array}$ & $\begin{array}{l}51.79 \\
\text { m/day }\end{array}$ \\
\hline $\begin{array}{l}\text { Yield of Alluvial } \\
\text { Bed }\left(Q_{G}\right)\end{array}$ & $Q_{G}=K A d h / d l$ & $\begin{array}{c}A=\text { Cross sectional area }\left(\mathrm{m}^{2}\right) \\
K=\text { Hydraulic conductivity }(\mathrm{m} / \text { day }) \\
d h / d l=\text { Hydraulic gradient }\end{array}$ & Darcy’s Law & $\begin{array}{c}308.876 \\
\mathrm{~m}^{3} / \text { day }\end{array}$ \\
\hline Packer Test & $\begin{array}{c}T=Q \ln \left(R / r_{b}\right) / 2 \pi P_{i} \\
K_{p}=T / L\end{array}$ & $\begin{array}{c}T=\text { transmissivity }\left(\mathrm{m}^{2} / \text { day }\right) . \\
Q=\text { injection rate }\left(\mathrm{m}^{3} / \text { day }\right) \text { and it was Zero. } \\
R=\text { radius of influence }(\mathrm{m}) . \\
r_{b}=\text { radius of borehole }(\mathrm{m}) . \\
P_{i}=\text { net injection pressure }(\mathrm{m}) . \\
T=\text { Transmissivity }\left(\mathrm{m}^{2} / \text { day }\right) . \\
L=\text { Length of test zone and equal to } 3 \mathrm{~m} .\end{array}$ & $\begin{array}{l}\text { Brassington } \\
\text { (2007) }\end{array}$ & 0 \\
\hline
\end{tabular}

Table 4. Standards of transmissivity ( $\mathrm{m}^{2} /$ day) [13].

\begin{tabular}{cc}
\hline Transmissivity (m²/Day) & Potential \\
\hline$>500$ & High \\
$500-50$ & Moderate \\
$50-5$ & Low \\
$5-0.5$ & Weak Negligible \\
\hline
\end{tabular}


same. This means that the water did not penetrate into the clay stone. Hence according to the above equations of transmissivity and permeability for the clay stone the values are equal to zero. This suggests that the clay stone is capable to retain water and prevent seepage to create an ideal location for water collection.

\section{Subsurface Dam Capacity}

Large parts of Garmiyan area suffers from shortage of water supply during dry periods. Rainfall, both spatially and temporally is decreasing due to the effect of climate change [14]-[18]. In addition, the situation becomes more severe where the populations growth rate is increasing. One of the solutions to this problem is increasing the water storage within the stream deposits to secure water supply to local communities.

The storage capacity of the subsurface dam within Isayi stream can be calculated depending on the surface area of the stream deposits upstream the project, average saturated thickness and effective porosity of the stream deposits. The yield of the stream deposits can be increased by building another subsurface dam at nearly $1 \mathrm{~km}$ upstream the first one as illustrated in Figure 11. Hence the upstream area of stream deposits, between the first subsurface dam and the confluence of Isayi stream's main two branches that can be exploited by both projects, will be $835,250 \mathrm{~m}^{2}$. The average saturated thickness is $4.5 \mathrm{~m}$, and the groundwater level (depth below the ground surface) is kept at a depth of $1 \mathrm{~m}$ to prevent evaporation as recommended by Hellwig [19], then, the calculated total storage capacity for the both subsurface dams is $1,014,829 \mathrm{~m}^{3}$ as shown in Table 3 . This storage capacity can retain nearly $1 / 3$ of the total stream discharge of Isayi stream that had been measured during (20112012) and compared with the rain fall during that period as it illustrated in Table 5, Table 6 . This ratio can be increased if additional subsurface dams constructed within the stream deposits upstream the suggested locations.

These projects can be applied in Garmiyan area beside each village with less cost to harvest the available surface and subsurface water. Figure 12 suggests that rainfall begins to recharge the subsurface water from autumn to the begging of the summer and the ceases effective surface runoff from January to the end of March.

\section{Water Utility}

According to the common water uses in the studied area, groundwater quality has been evaluated for domestic, irrigation and live stocks purposes as follow:

\subsection{Domestic Use}

The groundwater samples have been compared with drinking water standards that are prescribed by World Health Organization [21] and Iraqi drinking water standards [22] as given in Table 7.

The physical, chemical and biological characteristics of all samples indicated that groundwater within the stream deposits is suitable for drinking purpose with slight hardness regardless of the slight elevated groundwater temperature. Because subsurface water is recharged with rainfall rapidly and there is no dense urbanization and industrial developments in the upstream parts of the watershed to cause contamination.

\subsection{Irrigation Use}

Irrigation is the major agricultural practice in the watershed. Most of the farmers intensively use water from hand dug wells in the study area. Based on the EC, irrigation water can be classified into four categories [23] as shown in Table 8. Based on this classification, all the water samples are classified as C2 water class for irrigation.

\subsection{Livestock Use}

In the studied area, farmers use the ground water for their animals. Livestock water can be classified on the basis of TDS concentration [24] as illustrated in Table 9. According to this classification, all water samples in the study area are safe for livestock.

\section{Time of Construction}

Subsurface dams are generally built at the end of the dry season when there is minimum water in the aquifer [25]. The maximum variation of fluctuated water level was $20 \mathrm{~cm}$ which means that the interflow are not originated 


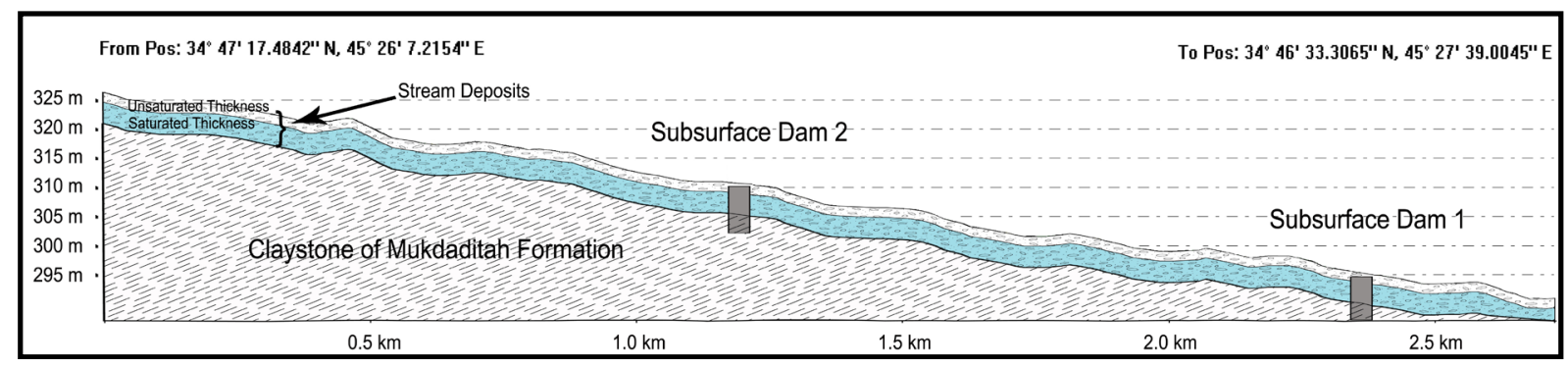

Figure 11. Longitudinal section along Isayi stream, illustrating location of the suggested subsurface dams with the stream deposits.

Table 5. Measured characteristics of stream deposits and assumed storage capacity of the subsurface dam.

\begin{tabular}{cccccc}
\hline $\begin{array}{c}\text { Subsurface Dam } \\
\text { NO. }\end{array}$ & $\begin{array}{c}\text { Dam Height } \\
(\mathrm{m})\end{array}$ & $\begin{array}{c}\text { Average Saturated } \\
\text { Thickness }(\mathrm{m})\end{array}$ & $\begin{array}{c}\text { Upstream area of the } \\
\text { stream deposits }\left(\mathrm{m}^{2}\right)\end{array}$ & $\begin{array}{c}\text { Porosity of the stream deposit } \\
{[11][20]}\end{array}$ & $\begin{array}{c}\text { Storage Capacity } \\
\left(\mathrm{m}^{3}\right)\end{array}$ \\
\hline 1 & $4-10$ & 4.5 & 434,330 & $20 \%-35 \%$ & $390,897-684,070$ \\
2 & $4-10$ & 4.5 & 400,920 & $20 \%-35 \%$ & $360,828-631,449$ \\
Total & - & - & 835,250 & $20 \%-35 \%$ & $751,725-1,315,519$ \\
\hline
\end{tabular}

Table 6. Water resource measurement within Isayi watershed.

\begin{tabular}{cccccccc}
\hline Months & $\begin{array}{c}\text { Rainfall } \\
(\mathrm{mm})\end{array}$ & $\begin{array}{c}\text { Rainfall }\left(\mathrm{m}^{3}\right) \text { based on } \\
\text { watershed upstream the projects }\end{array}$ & $\begin{array}{c}\text { Surface Flow } \\
\left(\mathrm{m}^{3}\right)\end{array}$ & $\begin{array}{c}\text { Surface } \\
\text { Flow }(\%)\end{array}$ & $\begin{array}{c}\text { Subsurface } \\
\text { Flow }\left(\mathrm{m}^{3}\right)\end{array}$ & $\begin{array}{c}\text { Surface \& } \\
\text { Subsurface Flow } \\
\left(\mathrm{m}^{3}\right)\end{array}$ & $\begin{array}{c}\text { Surface \& } \\
\text { Subsurface } \\
\text { Flow } \%\end{array}$ \\
\hline Sep. & 0 & 0 & 0 & 0.00 & 19175.77 & 19175.77 & Base Flow \\
Oct. & 0 & 0 & 0 & 0.00 & 19978.72 & 19978.72 & Base Flow \\
Nov. & 3.50 & 507,500 & 0 & 0.00 & 20205.87 & 20205.87 & Base Flow \\
Dec. & 7.40 & $1,073,000$ & 14257.78 & 0.18 & 20879.4 & 35137.18 & 0.42 \\
Jan. & 22.70 & $3,291,500$ & 195932 & 2.43 & 20879.4 & 216811.4 & 2.61 \\
Feb. & 39.50 & $5,727,500$ & 3625344 & 44.93 & 18985.59 & 3644329.59 & 43.84 \\
Mar. & 53.50 & $7,757,500$ & 3555783 & 44.07 & 21165.98 & 3576948.98 & 43.03 \\
Apr. & 27.30 & $3,958,500$ & 659021.2 & 8.17 & 20364.35 & 679385.55 & 8.17 \\
May & 11.50 & $1,667,500$ & 18752.78 & 0.23 & 20879.4 & 39632.18 & 0.48 \\
Jun. & 5.30 & 768,500 & 63.05 & 0.00 & 20126.63 & 20189.68 & Base Flow \\
Jul. & 0 & 0 & 0 & 0.00 & 20633.76 & 20633.76 & Base Flow \\
Aug. & 0 & 0 & 0 & 0.00 & 20142.48 & 20142.48 & Base Flow \\
Total & 170.70 & $24,751,500$ & 8069153.81 & 100 & 243417.35 & 8312571.16 & 100 \\
\hline
\end{tabular}

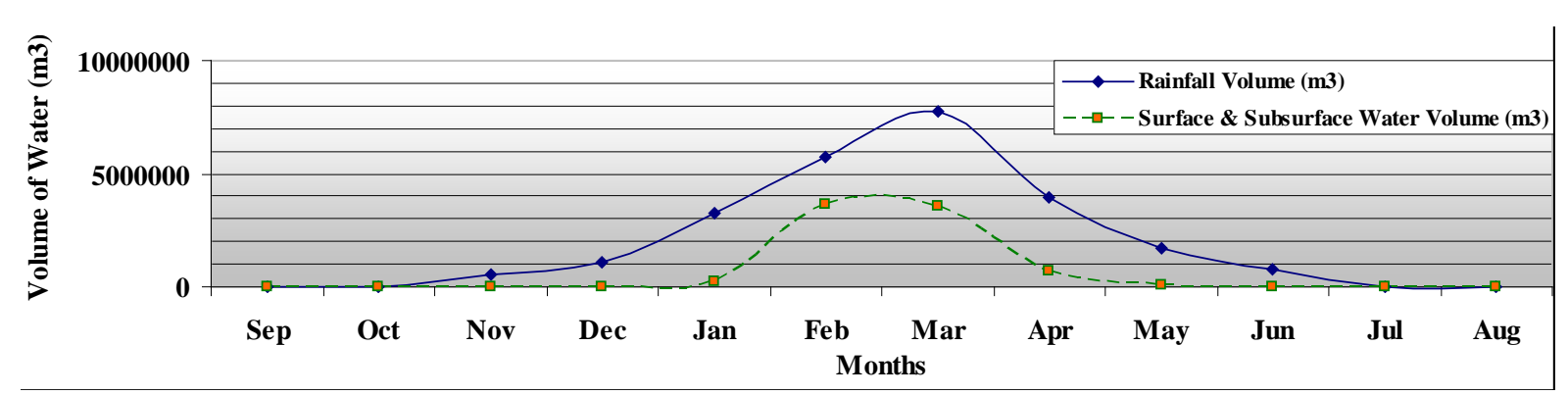

Figure 12. Available water resources in Isayi watershed.

from the rainfall only but also it has been recharged with water from base flow which originated from the neighboring and nearby aquifer especially Bai Hassan and Quaternary aquifer. The best time to undertake construction is at the dry season, because the lowest possible water table level is reached so that maximum water 
Table 7. Groundwater compared to drinking water standards.

\begin{tabular}{|c|c|c|c|c|c|c|}
\hline \multirow{2}{*}{ Parameters } & \multicolumn{3}{|c|}{ Range of Water samples } & \multicolumn{2}{|c|}{ Drinking Water Standard } & \multirow{2}{*}{$\begin{array}{l}\text { Groundwater Samples } \\
\text { Suitability }\end{array}$} \\
\hline & DW1 & DW2 & DW3 & (WHO, 2008) & Iraqi Standard (2000) & \\
\hline Temp. $\left({ }^{\circ} \mathrm{C}\right)$ & 26 & 26 & 26.1 & 25-Aug & & Suitable \\
\hline $\mathrm{pH}$ & 7.26 & 7.3 & 7.55 & $6.5-8.5$ & & Suitable \\
\hline $\mathrm{Ca}^{2+}$ & 90.63 & 90.8019 & 111.785 & 75 & 50 & Suitable \\
\hline $\mathrm{Mg}^{2+}$ & 17.244 & 17.562 & 19.959 & 125 & 50 & Suitable \\
\hline $\mathrm{Na}^{+}$ & 1.342 & 1.373 & 3.964 & 200 & 200 & Suitable \\
\hline $\mathrm{K}^{+}$ & 1.4 & 1.34 & 1.5 & 12 & - & Suitable \\
\hline $\mathrm{HCO}_{3}^{-}$ & 323.3 & 298.9 & 421.6 & - & - & Suitable \\
\hline $\mathrm{SO}_{2}^{-4}$ & 76 & 78 & 86 & 250 & 250 & Suitable \\
\hline $\mathrm{Cl}^{-}$ & 27 & 26 & 30 & 250 & 250 & Suitable \\
\hline $\mathrm{NO}_{2}^{-3}$ & 15.52 & 14.16 & 0 & 50 & 50 & Suitable \\
\hline $\mathrm{TH}$ & 297.275 & 299.009 & 361.294 & - & 500 & Suitable \\
\hline TDS & 552.436 & 528.1369 & 674.808 & 1000 & 1000 & Suitable \\
\hline Coliform & 0 & 0 & 0 & 0 & 50 & Suitable \\
\hline
\end{tabular}

Table 8. Water samples classification depending on EC [23].

\begin{tabular}{ccc} 
Level & EC $(\mu \mathrm{S} / \mathrm{cm})$ & Hazard and limitations \\
\hline C1 & $<250$ & Low hazard; no detrimental effects on plants, and no soil buildup expected. \\
C2 & $250-750$ & $\begin{array}{c}\text { Sensitive plants may show stress; moderate leaching prevents salt accumulation in soil. } \\
\text { Salinity will adversely affect most plants; requires selection of salt-tolerant plants, } \\
\text { careful irrigation, good drainage, and leaching. }\end{array}$ \\
C3 & $750-2250$ & $\begin{array}{r}\text { Generally unacceptable for irrigation, except for very salt tolerant plants, excellent drainage, } \\
\text { frequent leaching, and intensive management. }\end{array}$ \\
\hline
\end{tabular}

Table 9. Recommended TDS concentration limits for livestock consumption [24].

\begin{tabular}{cc}
\hline Stock & Hazard and limitations (ppm) \\
\hline Poultry & 2860 \\
Horses & 6435 \\
Cattle (Diary) & 7150 \\
Cattle (Beef) & 10,100 \\
Sheep & 12,900 \\
\hline
\end{tabular}

reserve is acquired and water logging during construction is minimized and intermediate work pauses are curbed so that the activity is completed on time.

According to the meteorological data, the peak of dry season is the end of summer and beginning of autumn seasons at the studied area, whereas on the basis of groundwater level observation information, the maximum lowering down level of groundwater for 2012 was the end of autumn season (end of November). Hence the best time to be chosen for construction of the subsurface dam is during the autumn season from September to November.

\section{Conclusions}

Garmiyan area suffers from water shortage problems such as poor absence of surface water resources and groundwater in many places as well as low rainfall rate. To overcome this problem subsurface water dams are to be suggested to serve as strategic water supply storage. The results suggested:

- The selected site location for the proposed subsurface dam within Isayi watershed is suitable lithologically because the bed of stream deposit is surrounded by claystone. In addition to that the geological and structural situations provide suitable condition for subsurface dam construction. 
- The GPR survey results revealed that no evidences of faults and cavities were recorded beneath the whole area under consideration.

- The geomorphologic investigations revealed that outlet of Isayi watershed collect high amount of surface and subsurface water; the stream deposits are perfect landform for water conservation that is surrounded by claystone preventing irregular water bypaths and leakage; and the slope is level to very gentle which is within the recommended range.

- The hydrogeologic surveys indicated that the selected site location for the project is suitable. This is due to the very low fluctuation of groundwater level in the boreholes, the pumping test revealed high productivity of stream deposits and the result of packer test indicated that the lower claystone layer is able to retain water and prevent seepage.

- Analyzed water samples suggest that it is suitable for domestic, irrigation and livestock purposes.

- The best time to be chosen for the construction of the proposed subsurface dam is during autumn i.e. from September to November.

\section{References}

[1] Ishida, S., Kotoku, M., Abe, E., Fazal, M.A., Tsuchihara, T. and Imaizumi, M. (2003) Construction of Subsurface Dam and Their Impact on the Environment. RMZ-Materials and Geoenvironment, 50, 149-152.

[2] Borst, L. and de Haas, S.A. (2006) Hydrology of Sand Storage Dams: A Case Study in the Kiindu Catchment, Kitui District, Kenya. Master Thesis of Hydrogeology, VU University, Amsterdam.

[3] Hoogmoed, M. (2007) Analyses of Impacts of a Sand Storage Dam on Groundwater Flow and Storage Groundwater Flow Modelling in Kitui District, Kenya. Master Thesis Hydrogeology, VU University, Amsterdam.

[4] Şen, Z. (2008) Wadi Hydrology. Taylor \& Francis Group, Istanbul Technical University, Turkey.

[5] Khairy, A.T., Al-Ghamdi, A.S. and Gutub, S.A. (2010) Analysis and Design of a Deep Subsurface Dam. International Journal of Civil \& Environmental Engineering IJCEE-IJENS, 10, 03, 10p.

[6] Jassim, S.Z. and Goff, J.C. (2006) Geology of Iraq. Dolin, Prague and Moravian Museum, Brno.

[7] Nilsson, A. (1988) Groundwater Dams for Small-Scale Water Supply. IT Publications, London. http://dx.doi.org/10.3362/9781780442297

[8] Danida (Danish International Development Assistance) (2006) Water From Dry Riverbeds. Technical Handbook, Royal Danish Embassy in Kenya.

[9] Ali, I. (2010) Locating Suitable Sites for Constructing Subsurface Dams Using GIS. M.Sc. Thesis, Royal Institute of Technology (KTH), Stockholm, Trita Vol. 10, 21p.

[10] Raghunath, H.M. (2006) Hydrology (Principles, Analysis Design). 2nd Edition, New Age International (P) Ltd., New Delhi.

[11] Fetter, C.W. (2001) Applied Hydrogeology. 4th Edition, Pearson, Higher Education, New Jersey.

[12] Brassington, R. (2007) Field Hydrogeology. 3rd Edition, John Wiley \& Sons, London.

[13] Şen, Z. (1995) Applied Hydrogeology for Engineers and Scientists. CRC Lewis Publishers, Boca Raton.

[14] Al-Ansari, N.A. (2013) Management of Water Resources in Iraq: Perspectives and Prognoses. Engineering, 5, 667684.

[15] Al-Ansari, N.A., Abdellatif, M., Ali, S. and Knutsson, S. (2014) Long Term Effect of Climate Change on Rainfall in Northwest Iraq. Central European Journal of Engineering. (accepted)

[16] Al-Ansari, N.A., Abdellatif, M., Ezeelden, M., Ali, S. and Knutsson, S. (2014) Climate Change and Future Long Term Trends of Rainfall at North-Eastern Part of Iraq. Journal of Civil Engineering and Architecture, 8, 790-805.

[17] Al-Ansari, N.A., Abdellatif, M., Zakaria, S., Mustafa, Y. and Knutsson, S. (2014) Future Prospects for Macro Rainwater Harvesting (RWH) Technique in North East Iraq. Journal of Water Resource and Protection, 6, 403-420. http://dx.doi.org/10.4236/jwarp.2014.65041

[18] Al-Ansari, N.A., Abdellatif, M., Al-Khateeb, M. and Knutsson, S. (2014) Desertification and Future Rainfall Trends North Iraq. 8th Edition of the International Scientific Congress of GIS and Geospacealications Geotunis, Tunis/ Hammamet, 2-6 April 2014, 24.

[19] Hellwig, D.H.R. (1973) Evaporation of Water from Sand 4: The Influence of the Depth of The Water Table and Particle Size Distribution of the Sand. Journal of Hydrology, 18, 317-327. http://dx.doi.org/10.1016/0022-1694(73)90055-3

[20] Fitts, C.R. (2002) Groundwater Science. Elsevier, London. 
[21] WHO (World Health Organization) (2008) Guideline for Drinking Water Quality. 3rd Edition, Vol. 1, Recommendations, World Health Organization, Geneva.

[22] Iraqi Drinking Water Specification (2000) Baghdad Water Administration Authority.

[23] College of Agricultural Sciences (2002) Irrigation Water Quality. The Pennsylvania State University, University Park. http://www.cas.psu.edu/docs/casdept/Turf/Education/Turgeon/CaseStudy/OldRanch/IrrWatQual.html

[24] McKee, J.E. and Wolf, H.W. (1963) Water Quality Criteria. California State Water Quality Control Board Publication, 3-A, 548p.

[25] Yilmaz, M. (2003) Control of Groundwater by Underground Dams. M.Sc. Thesis, Department of Civil Engineering, METU, Ankara. 
Scientific Research Publishing (SCIRP) is one of the largest Open Access journal publishers. It is currently publishing more than 200 open access, online, peer-reviewed journals covering a wide range of academic disciplines. SCIRP serves the worldwide academic communities and contributes to the progress and application of science with its publication.

Other selected journals from SCIRP are listed as below. Submit your manuscript to us via either submit@scirp.org or Online Submission Portal.
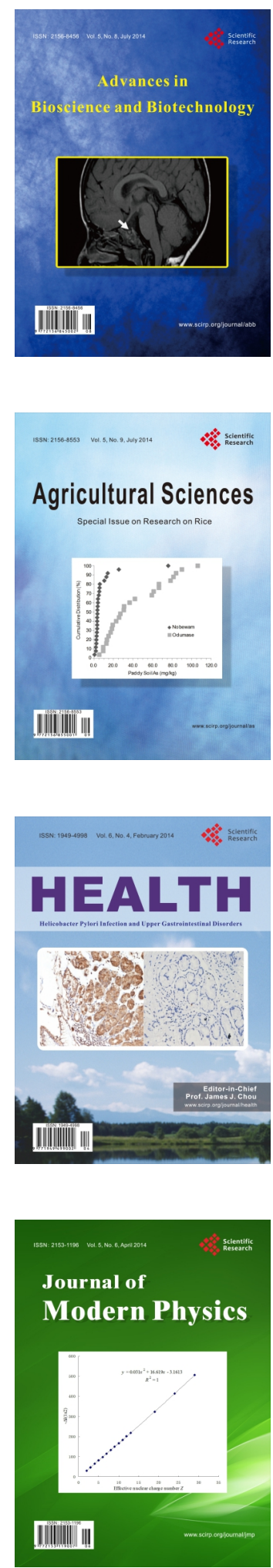
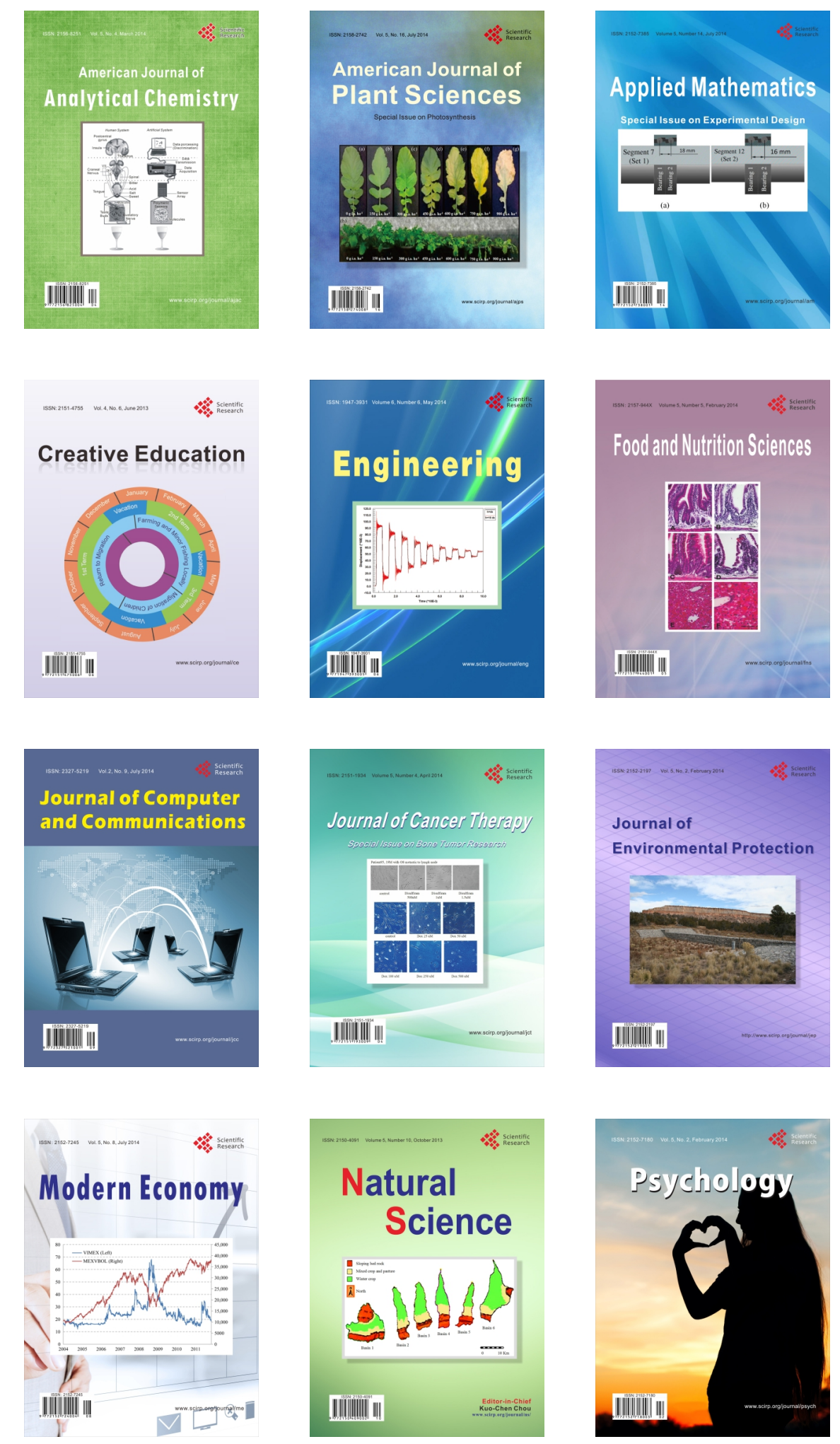